\title{
MODELLING OF POWER SUPPLIES RELIABILITY IN ASPECT OF THEIR TECHNICAL AND FUNCTIONAL STATE
}

\section{MODELOWANIE NIEZAWODNOŚCI ZASILACZY W ASPEKCIE STANU TECHNICZNEGO I FUNKCJONALNEGO}

\author{
Tadeusz Dąbrowski ${ }^{1}$, Jerzy Chmiel ${ }^{2}$, Adam Rosiński ${ }^{1}$ \\ ${ }^{1}$ Military University of Technology Faculty of Electronics \\ Wojskowa Akademia Techniczna Wydział Elektroniki \\ ${ }^{2}$ Warsaw University of Technology Faculty of Transport \\ Politechnika Warszawska Wydział Transportu
}

\begin{abstract}
The article presents issues related to the modeling of reliability of power supply in terms of their technical and functional condition. There are designated relations allowing to determine the probability of staying the power supply in the state: full suitability, incomplete suitability and unsuitability. There is also examined the impact of time restore of the state of full suitability for the value of the probability of staying the power supply in the state of incomplete suitability.
\end{abstract}

Keywords: reliability, power supply, exploitation process

Streszczenie: $W$ artykule przedstawiono zagadnienia zwiazane z modelowaniem niezawodności zasilaczy $w$ aspekcie ich stanu technicznego i funkcjonalnego. Wyznaczono zależności pozwalajace określić prawdopodobieństwo przebywania zasilacza w stanie: petnej zdatności, niepetnej zdatności i niezdatności. Dokonano równiez analizy wpływu czasu przywrócenia stanu petnej zdatności na wartość prawdopodobieństwa przebywania zasilacza w stanie niepetnej zdatności.

Stowa kluczowe: niezawodność, zasilacz, proces eksploatacji 
Modelling of power supplies reliability in aspect of their technical...

Modelowanie niezawodności zasilaczy w aspekcie stanu technicznego...

\section{MODELLING OF POWER SUPPLIES RELIABILITY IN ASPECT OF THEIR TECHNICAL AND FUNCTIONAL STATE}

\section{Introduction}

During exploitation of any object, including power supplies, as a result of, among others, the impact of various external factors, occurs degradation of the technical characteristics - as well as the successive functional characteristics of these objects. This means that inevitably each of the exploited object, after a while, changes the original full suitability state (technical and functional)to the state of incomplete suitability - and ultimately the state of unsuitability. There are known models of exploitation process of the contractual power supply with the consideration of the parameters of the different transitions between states of full suitability $\mathrm{S}_{\mathrm{PZ}}$, incomplete suitability $S_{N Z}$ and the unsuitability $S_{N}$ [13]. In this context, an interesting case - and not yet fully described - seems to be a situation in which the user of power supply does not take any action to restore the state $S_{\mathrm{PZ}}$. Such an event can occur when there is a lack of financial resources to take action in order to fully repair the device or there is a shortage of time for such activities. The power supply should then be able to operate in the state incomplete suitability but maintaining the desired properties of offered power on its output . This article tries to analyze the reliability of power supplies in the context of technical and functional incomplete suitability.

Reliability theory abounds, in terms of general considerations, in an established literature foundation $[2,6]$. Presented in these publications frames of systems reliability enable the linking of their structure (eg.: serial, parallel, serial-toparallel) with specific indicators describing reliability. This in turn allows the determination of graphs of transitions between highlighted exploitation states $[5,12,13]$. Using a specific mathematical apparatus (eg. the equation KolmogorovChapman) it is possible to determine the probability of the system staying in the distinguished states $[15,18]$. This method is also suitable for use in the reliability analysis of power supplies.

In [1] presented an analysis of the reliability of power systems. Particular attention was paid here to the emergency power systems (both types of static and dynamic). The use of such systems increases the value of the indicator of readiness of the whole power system.

Considerations relating to the reliability of the power system are shown in many literature references. Among them, to the most important may included positions [3.21]. The use of redundant power sources is described in publications [24,25]. The particular attention is paid to the emergency power systems (uninterruptible power supplies UPS, generating sets, ecological solutions in the form of solar panels or electric power generators driven by wind). The analysis of these solutions leads to the conclusion that their use can increase the value of reliabilityexploitation indicators of power systems. 
The power supplies used in transport (both to power ICT systems and vehicles $[7,11,23])$, and in particular in transport safety systems $[8,20,26]$ are required to meet a number of important criteria. These should include, among others, the high efficiency, miniaturization, appropriate functionality, compliance with the law [9], high reliability $[10,14]$, the ability to diagnose the respective exploitation states with regard to the quality of information [22], immunity to electromagnetic interference $[16,17,19]$ and vibration [4]. Fulfilling of these expectations requires the knowledge of the credible models reliability- exploitation models of power systems.

\section{Reliability analysis of power supplies}

During the reliability-exploitation analysis of power supply, it can be concluded that the relationship taking place in it can be presented as in Fig. 1. This figure does not include all cases of possible changes of the state of power supply (eg. does not show the transition from the state of unsuitability $S_{N}$ to of full suitability $S_{\mathrm{PZ}}$ ).

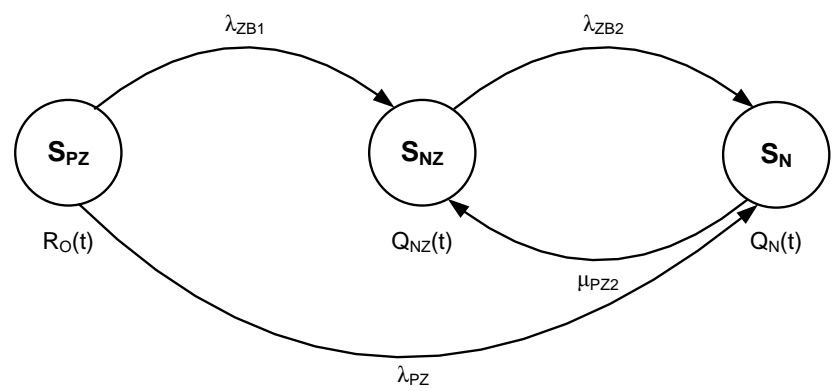

Fig. 1 Relations in power supplies [own elaboration]

Denotations in figures 1: $R_{O}(t)$ - the function of probability of system staying in state of full suitability $S_{P Z}, Q_{N Z}(t)$ - the function of probability of system staying in state of the unsuitability $S_{N Z}, Q_{N}(t)$ - the function of probability of system staying in state of unsuitability $S_{N}, \lambda_{Z B 1}$ transition rate from the state of full suitability $S_{P Z}$ into the state of the incomplete suitability $S_{N Z}, \lambda_{Z B 2}$ - transition rate from the state of the unsuitability $S_{N Z}$ into the state of unsuitability $S_{N}, \mu_{P Z 2}$ - transition rate from the state of unsuitability $S_{N}$ into the state of the incomplete suitability $S_{N Z}, \lambda_{P Z}$ - transition rate from the state of full suitability $S_{P Z}$ into the state of incomplete suitability $S_{N}$.

State of full suitability $S_{\mathrm{PZ}}$ is a state signifying both the technical and functional suitability. The power supply meets all the exploitation requirements. State of incomplete suitability $\mathrm{S}_{\mathrm{NZ}}$ is a state denoting incomplete technical suitability and limited (eg. in terms of time of use and / or the level of generated power) functional fitness. State of unsuitability $S_{N}$ is the state meaning both technical and functional unsuitability. The power supply does not meet most of the exploitation requirements.

If the power system is in the state of full suitability $\mathrm{S}_{\mathrm{PZ}}$ and there occurs noncritical damage, system is a transition to a state of incomplete suitability $\mathrm{S}_{\mathrm{NZ}}$ with the intensity $\lambda_{\mathrm{ZB} 1}$. 
Modelling of power supplies reliability in aspect of their technical...

Modelowanie niezawodności zasilaczy w aspekcie stanu technicznego...

When there is a state of incomplete suitability $\mathrm{S}_{\mathrm{NZ}}$ and additionally appears critical damage so there is transition to a state of $S_{N}$ with intensity $\lambda_{\mathrm{ZB} 2}$. Redeemable transition to a state of incomplete suitability $S_{\mathrm{NZ}}$ from the state unsuitability $\mathrm{S}_{\mathrm{N}}$ is possible if there are provided actions to restore the required (ie. at least admissible) properties of energy at the output of the power supply.

When there is a state of of full suitability $\mathrm{S}_{\mathrm{PZ}}$ and appears critical damage, it results in a transition to a state of unsuitability $\mathrm{S}_{\mathrm{N}}$.

The system illustrated in fig. 1 may be described by the following ChapmanKolmogorov equations:

$$
\begin{aligned}
& R_{0}^{\prime}(t)=-\lambda_{Z B 1} \cdot R_{0}(t)-\lambda_{P Z} \cdot R_{0}(t) \\
& Q_{N Z}^{\prime}(t)=\lambda_{Z B 1} \cdot R_{0}(t)-\lambda_{Z B 2} \cdot Q_{N Z}(t)+\mu_{P Z 2} \cdot Q_{N}(t) \\
& Q_{N}^{\prime}(t)=\lambda_{Z B 2} \cdot Q_{N Z}(t)-\mu_{P Z 2} \cdot Q_{N}(t)+\lambda_{P Z} \cdot R_{0}(t)
\end{aligned}
$$

Given the initial conditions:

$$
\begin{aligned}
& R_{0}(0)=1 \\
& Q_{N Z}(O)=Q_{N}(O)=0
\end{aligned}
$$

Laplace transform yields the following system of linear equations:

$$
\begin{aligned}
& s \cdot R_{0}^{*}(s)-1=-\lambda_{Z B 1} \cdot R_{0}^{*}(s)-\lambda_{P Z} \cdot R_{0}^{*}(s) \\
& s \cdot Q_{N Z}^{*}(s)=\lambda_{Z B 1} \cdot R_{0}^{*}(s)-\lambda_{Z B 2} \cdot Q_{N Z}^{*}(s)+\mu_{P Z 2} \cdot Q_{N}^{*}(s) \\
& s \cdot Q_{N}^{*}(s)=\lambda_{Z B 2} \cdot Q_{N Z}^{*}(s)-\mu_{P Z 2} \cdot Q_{N}^{*}(s)+\lambda_{P Z} \cdot R_{0}^{*}(s)
\end{aligned}
$$

Probabilities of system staying in a distinguished functional states in symbolic (Laplace) terms have the following form:

$$
\begin{gathered}
R_{0}^{*}(s)=\frac{1}{s+\lambda_{P Z}+\lambda_{Z B 1}} \\
Q_{N Z}^{*}(s)=\frac{s \cdot \lambda_{Z B 1}+\lambda_{P Z} \cdot \mu_{P Z 2}+\lambda_{Z B 1} \cdot \mu_{P Z 2}}{s^{2} \cdot \lambda_{P Z}+s^{2} \cdot \lambda_{Z B 1}+s^{2} \cdot \lambda_{Z B 2}+s^{2} \cdot \mu_{P Z 2}+s^{3}+} \\
+s \cdot \lambda_{P Z} \cdot \lambda_{Z B 2}+s \cdot \lambda_{P Z} \cdot \mu_{P Z 2}+s \cdot \lambda_{Z B 1} \cdot \lambda_{Z B 2}+s \cdot \lambda_{Z B 1} \cdot \mu_{P Z 2} \\
Q_{N}^{*}(s)=\frac{s \cdot \lambda_{P Z}+\lambda_{P Z} \cdot \lambda_{Z B 2}+\lambda_{Z B 1} \cdot \lambda_{Z B 2}}{s^{2} \cdot \lambda_{P Z}+s^{2} \cdot \lambda_{Z B 1}+s^{2} \cdot \lambda_{Z B 2}+s^{2} \cdot \mu_{P Z 2}+s^{3}+} \\
+s \cdot \lambda_{P Z} \cdot \lambda_{Z B 2}+s \cdot \lambda_{P Z} \cdot \mu_{P Z 2}+s \cdot \lambda_{Z B 1} \cdot \lambda_{Z B 2}+s \cdot \lambda_{Z B 1} \cdot \mu_{P Z 2}
\end{gathered}
$$

Solution to the above set of equations in the time domain is the next step in the analysis and is not discussed here. 


\section{Modeling of reliability of power supplies}

Computer simulation and computer-aided analysis facilitate to relatively quickly determine the influence of change in reliability-exploitation parameters of individual components on reliability of the entire system. Of course, the reliability structure of both the entire system and its components has to be known beforehand. Using computer aided allows to perform the calculation of the value of probability of system staying in state of full suitability $R_{O}$. That procedure is illustrated with below example.

Example

The following quantities were defined for the system:

- test duration - 1 year (values of this parameter is given in [h]):

$$
\mathrm{t}=8760[h]
$$

- reliability of power supply (in terms of non-critical defects)):

$$
\mathrm{R}_{\mathrm{ZB} 1}(t)=0,999
$$

- reliability of power supply (in terms of critical defects):

$$
\mathrm{R}_{\mathrm{ZB} 2}(t)=0,9999
$$

- transition rate from the state of unsuitability into the state of the incomplete suitability:

$$
\mu_{\mathrm{PZ} 2}=0,1\left[\frac{1}{h}\right]
$$

- transition rate from the state of full suitability into the state of incomplete suitability:

$$
\lambda_{\mathrm{PZ}}=1,141558 \cdot 10^{-9}\left[\frac{1}{h}\right]
$$

Knowing the value of reliability $\mathrm{R}_{\mathrm{ZB} 1}(t)$, transition rate from the state of full suitability into the state of the incomplete suitability may be estimated. Provided the up time is described by exponential distribution, the following relationship can be used:

$$
\mathrm{R}_{\mathrm{ZB} 1}(\mathrm{t})=\mathrm{e}^{-\lambda_{\mathrm{ZB} 1} \mathrm{t}} \text { for } t \geq 0
$$

thus

$$
\lambda_{\mathrm{ZB} 1}=-\frac{\operatorname{lnR} \mathrm{ZB}_{\mathrm{ZB} 1}(\mathrm{t})}{\mathrm{t}}
$$

For $\mathrm{t}=8760[h]$ and $\mathrm{R}_{\mathrm{ZB} 1}(t)=0,999$ we obtain: 
Modelling of power supplies reliability in aspect of their technical...

Modelowanie niezawodności zasilaczy w aspekcie stanu technicznego...

$$
\lambda_{\mathrm{ZB} 1}=-\frac{\ln \mathrm{R}_{\mathrm{ZB} 1}(\mathrm{t})}{\mathrm{t}}=-\frac{\ln 0,999}{8760}=1,142124 \cdot 10^{-7}\left[\frac{1}{\mathrm{~h}}\right]
$$

Knowing the value of reliability $\mathrm{R}_{\mathrm{ZB} 2}(t)$, transition rate from the state of the incomplete suitability into the state of the unsuitability may be estimated. Provided the up time is described by exponential distribution, the following relationship can be used:

$$
\mathrm{R}_{\mathrm{ZB} 2}(\mathrm{t})=\mathrm{e}^{-\lambda_{\mathrm{ZB} 2} \mathrm{t}} \text { for } t \geq 0
$$

thus

$$
\lambda_{\mathrm{ZB} 2}=-\frac{\ln \mathrm{R}_{\mathrm{ZB} 2}(\mathrm{t})}{\mathrm{t}}
$$

For $\mathrm{t}=8760[h]$ and $\mathrm{R}_{\mathrm{ZB} 2}(t)=0,9999$ we obtain:

$$
\lambda_{\mathrm{ZB} 2}=-\frac{\ln \mathrm{R}_{\mathrm{ZB} 2}(\mathrm{t})}{\mathrm{t}}=-\frac{\ln 0,9999}{8760}=1,141609 \cdot 10^{-8}\left[\frac{1}{\mathrm{~h}}\right]
$$

For above initial values, by use of (4) equations, following results are obtained:

$$
\begin{aligned}
& R_{0}=0,99899 \\
& Q_{Z B}=0,0010099 \\
& Q_{B}=1,151923 \cdot 10^{-8}
\end{aligned}
$$

Transition rate from the state the unsuitability to the state of the incomplete suitability $\mu_{P Z 2}$ is - for exponential distribution - time inverse $t_{P Z 2}$ :

$$
\mu_{P Z 2}=\frac{1}{t_{P Z 2}}
$$

Assuming the time of restoring the state the incomplete suitability $t_{P Z 2}$ falls within the interval $t_{P Z 2} \in\langle 12 ; 168\rangle[h]$ (i.e. after recalculation into days $\left.t_{P Z 2} \in\langle 0,5 ; 7\rangle[d a y]\right)$, the probability of staying of the analyzed power supply in the state of incomplete suitability is presented at Fig. 2. The value of time $t_{P Z 2}$ are adopted on the basis of observations of real systems. 


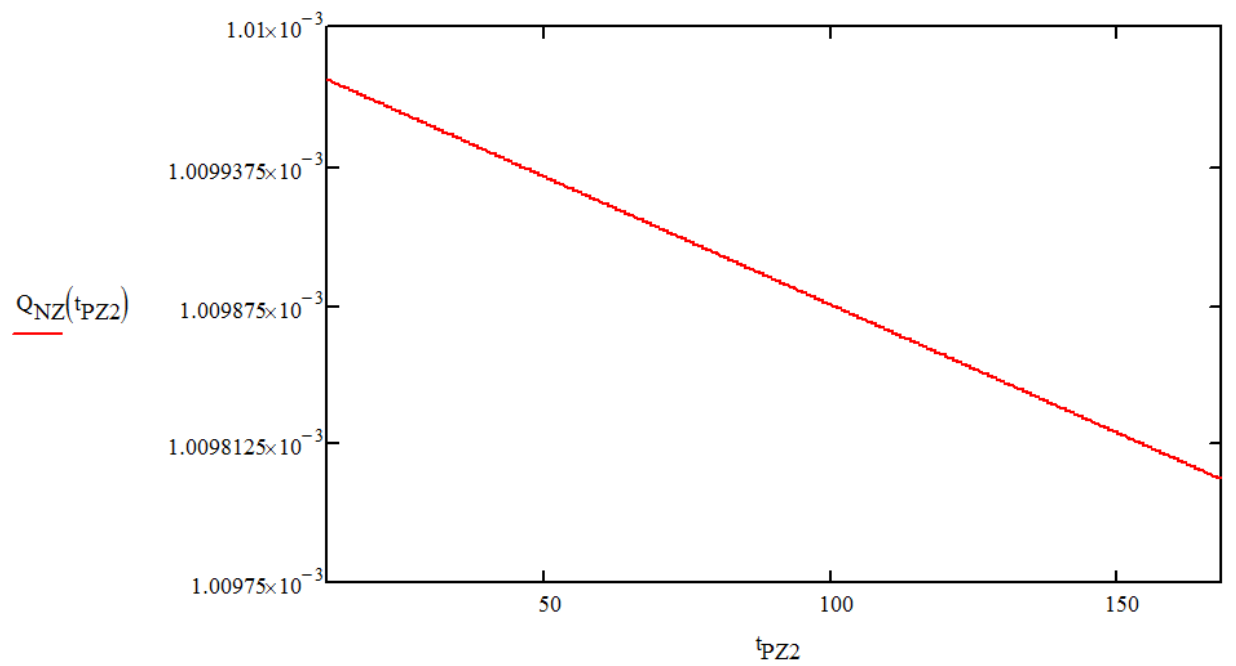

Fig. 2 The relationship between probability of power supply in the state of incomplete suitability $S_{N Z}$ as a function of time taken to incomplete suitability $t_{P Z 2}$ [own elaboration]

\section{Conclusion}

The paper presents the analysis of fragments of the reliability of the power supply with a special emphasis on distinguishing its states of unsuitability and incomplete suitability. Presented graph shows the reliability relationship of the power supply. There are designated relations allowing to determine the probability of staying the power supply in the distinguished states. In further studies of this problem it is reasonable to identify the relationship between the financial expenditures associated with the available and required time to restore the state of incomplete suitability and full suitability, and the reliability of staying of system in those states.

\section{References}

[1] Baggini A.: (editor) Handbook of power quality. John Wiley \& Sons, 2008.

[2] Będkowski L., Dąbrowski T.: Basics of exploitation, vol. II Basic of operational reliability. Military University of Technology, Warsaw 2006.

[3] Billinton R., Allan R. N.: Reliability evaluation of power systems. New York: Plenum Press, 1996.

[4] Burdzik R., Konieczny Ł., Figlus T.: Concept of on-board comfort vibration monitoring system for vehicles. J. Mikulski (Ed.): Activities of Transport Telematics, TST 2013, CCIS 395. Springer, Heidelberg 2013. pp. 418-425.

[5] Dyduch J., Paś J., Rosiński A.: The basis of the exploitation of transport electronic systems. Publisher Technical University of Radom, Radom 2011.

[6] Epstein B., Weissman I.: Mathematical models for systems reliability. CRC Press / Taylor \& Francis Group, 2008. 
Modelling of power supplies reliability in aspect of their technical...

Modelowanie niezawodności zasilaczy w aspekcie stanu technicznego...

[7] Kasprzyk Z., Siergiejczyk M.: Some Problems of Functional Analysis of Electronic Toll Collection System (ViaToll). In the monograph Activities of transport telematics, given as the monographic publishing series „Communications in Computer and Information Science”, Vol. 395. SpringerVerlag, Berlin Heidelberg, 2013, pp. 426-432.

[8] Kierzkowski A., Kisiel T.: Airport security screeners reliability analysis. In: „Proceedings of the IEEE International Conference on Industrial Engineering and Engineering Management IEEM 2015", Singapore 2015. pp. 1158-1163.

[9] Krzykowski M.: Protection of vulnerable customers of electricity and gaseous fuels - legal conditions. Polityka Energetyczna - Energy Policy Journal, vol. 17, no. 3, 2014. str. 257-268.

[10] Laskowski D., Łubkowski P., Pawlak E., Stańczyk P.: Anthropotechnical systems reliability. In: the monograph „Safety and Reliability: Methodology and Applications - Proceedings of the European Safety and Reliability Conference ESREL 2014”, editors: Nowakowski T., Młyńczak M., JodejkoPietruczuk A. \&Werbińska-Wojciechowska S. CRC Press/Balkema, London, 2015, pp. 399-407.

[11] Lewczuk K., Zak J., Pyza D., Jacyna-Gołda I.: Vehicle routing in an urban area: Environmental and technological determinants. WIT Transactions on the Built Environment, Vol.130, 2013. pp. 373-384.

[12] Paś J.: Operation of electronic transportation systems. Publishing House University of Technology and Humanities in Radom 2015.

[13] Rosiński A.: Modelling the maintenance process of transport telematics systems. Publishing House Warsaw University of Technology, Warsaw 2015.

[14] Rosiński A.: Reliability-exploitation analysis of power supply in transport telematics system. In: „Safety and Reliability: Methodology and Applications - Proceedings of the European Safety and Reliability Conference ESREL2014", editors: Nowakowski T., Młyńczak M., Jodejko-Pietruczuk A.,Werbińska-Wojciechowska S. CRC Press/Balkema, 2015. pp. 343-347.

[15] Siergiejczyk M., Krzykowska K., Rosiński A.: Reliability assessment of integrated airport surface surveillance system. In: „Proceedings of the Tenth International Conference on Dependability and Complex Systems DepCoSRELCOMEX”, editors: W. Zamojski, J. Mazurkiewicz, J. Sugier, T. Walkowiak, J. Kacprzyk, given as the monographic publishing series „Advances in intelligent systems and computing”, Vol. 365. Springer, 2015, pp. 435-443.

[16] Siergiejczyk M., Paś J., Rosiński A.: Issue of reliability-exploitation evaluation of electronic transport systems used in the railway environment with consideration of electromagnetic interference. IETIntelligent Transport Systems 2016, doi: 10.1049/iet-its.2015.0183.

[17] Siergiejczyk M., Paś J., Rosiński A.: Train call recorder and electromagnetic interference. Diagnostyka 2015, vol. 16, no. 1, pp. 19-22.

[18] Siergiejczyk M., Rosiński A., Krzykowska K.: Reliability assessment of supporting satellite system EGNOS. In W. Zamojski, J. Mazurkiewicz, J. Sugier, T. Walkowiak, J. Kacprzyk (eds) New results in dependability and computer systems, given as the monographic publishing series - „Advances in intelligent and soft computing", Vol. 224. Springer, 2013. pp. 353-364. 
[19] Siergiejczyk M., Rosiński A., Paś J.: Analysis of unintended electromagnetic fields generated by safety system control panels. Diagnostyka 2016, vol. 17, no. 3, pp. 35-40.

[20] Skorupski J., Uchroński P.: A fuzzy reasoning system for evaluating the efficiency of cabin luggage screening at airports. TransportationResearch Part C - Emerging Technologies 54, 2015, pp. 157-175.

[21] Sozański J.: Reliability and operating quality of electric power system. Warsaw: WNT, 1990.

[22] Stawowy M., Dziula P.: Comparison of uncertainty multilayer models of impact of teleinformation devices reliability on information quality. In: "Proceedings of the European Safety and Reliability Conference ESREL 2015”, editors: L. Podofillini, B. Sudret, B. Stojadinovic, E. Zio, W. Kröger. CRC Press/Balkema, 2015. pp. 2685-2691.

[23] Sumila M.: Selected aspects of message transmission management in ITS systems. In: the monograph „Telematics in the transport environment”, editors: Jerzy Mikulski, given as the monographic publishing series „Communications in Computer and Information Science”, Vol. 329. SpringerVerlag, Berlin Heidelberg 2012, pp. 141-147.

[24] Wiatr J., Miegoń M.: UPS power supplies and accumulator batteries in emergency power systems. Publishing House MEDIUM, Warsaw 2008.

[25] Wiatr J.: Generating sets in building emergency power systems. Publishing House MEDIUM, Warsaw 2009.

[26] Wiśnios M., Dąbrowski T., Bednarek M.: The security increasing level method provided by biometric access control system. Przegląd Elektrotechniczny 2015, no 10, pp. 229-232.

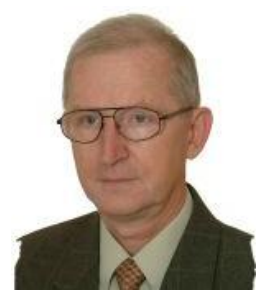

Assoc. Eng. Tadeusz Dabrowski - research interests are focused in the area of the theory of exploitation - mainly on technical diagnosis. The most important issues it deals with are: diagnostics of technical facilities and systems of anthropotechnical, optimization of diagnostic and maintenance, operational reliability objects (Share 33,3\%).

Jerzy Chmiel Ph.D. Eng. - scientific fields of interest of the paper co-author concern different aspects of electronic equipment reliability, especially from perspective of their applications in transport telematic systems, issues of their safety and operation (Share 33,3\%).

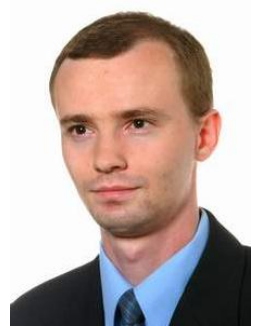

Assoc. Eng. Adam Rosiński - research interests include the analysis of reliability-exploitation transport systems telematics and intelligent transport systems. The scientific output has dozens of scientific publications (Share 33,3\%). 
Modelling of power supplies reliability in aspect of their technical...

Modelowanie niezawodności zasilaczy w aspekcie stanu technicznego...

\section{MODELOWANIE NIEZAWODNOŚCI ZASILACZY W ASPEKCIE STANU TECHNICZNEGO I FUNKCJONALNEGO}

\section{Wstęp}

Podczas eksploatacji dowolnego obiektu, w tym także zasilaczy, w wyniku m. in. oddziaływania różnorodnych czynników zewnętrznych, następuje degradacja właściwości technicznych - a w następstwie także funkcjonalnych - tych obiektów. Oznacza to, że nieuchronnie każdy z eksploatowanych obiektów, po jakimś czasie, zmienia pierwotny stan zdatności (technicznej i funkcjonalnej) na stan częściowej zdatności - a ostatecznie na stan niezdatności. Znane są modele procesu eksploatacji umownego zasilacza $z$ uwzględnieniem parametrów różnych przejść między stanami pełnej zdatności $S_{\mathrm{PZ}}$, niepełnej zdatności $\mathrm{S}_{\mathrm{NZ}}$ i niezdatności $\mathrm{S}_{\mathrm{N}}[13]$.W tym kontekście interesującym przypadkiem - a dotychczas nie w pełni opisanym - wydaje się sytuacja, w której użytkownik zasilacza nie podejmuje działań w celu przywrócenia stanu $\mathrm{S}_{\mathrm{PZ}}$. Zdarzenie takie może zaistnieć, gdy brak jest środków finansowych na podjęcie działań w celu pełnej naprawy urządzenia lub istnieje deficyt czasu dla takich działań. Zasilacz powinien wówczas funkcjonować $\mathrm{w}$ stanie niepełnej zdatności lecz $\mathrm{z}$ zachowaniem wymaganych właściwości oferowanej na jego wyjściach energii. Niniejszy artykuł zawiera próbę analizy niezawodności zasilaczy $\mathrm{w}$ aspekcie niepełnej zdatności technicznej i funkcjonalnej.

Teoria niezawodności obfituje, w zakresie rozważań ogólnych, ugruntowaną podbudowę literaturową $[2,6]$. Zaprezentowane $w$ tych publikacjach ujęcia niezawodności systemów umożliwiają powiązanie ich struktury(np.: szeregowej, równoległej, szeregowo-równoległej) z określonymi wskaźnikami opisującymi niezawodność. To z kolei pozwala na wyznaczenie grafów przejść pomiędzy wyróżnionymi stanami eksploatacyjnymi $[5,12,13]$. Stosując określony aparat matematyczny (np. równania Kołmogorowa-Chapmana) można wyznaczyć wartości prawdopodobieństw przebywania systemu w wyróżnionych stanach $[15,18]$. Taka metoda nadaje się do zastosowana także $w$ analizie niezawodnościowej zasilaczy.

W [1] przedstawiono analizę niezawodnościową systemów zasilających. Szczególną uwagę zwrócono tu na systemy zasilania awaryjnego (zarówno typu statycznego jak i dynamicznego). Zastosowanie takich systemów zwiększa wartość wskaźnika gotowości całego systemu zasilania.

Rozważania odnoszące się do niezawodności systemów zasilania przedstawiane są w wielu pozycjach literaturowych. Wśród nich do najbardziej znaczących można zaliczyć pozycje [3,21]. Zastosowanie rezerwowych źródeł zasilania opisano $\mathrm{m}$. in. w publikacjach [24,25]. Zwrócono przy tym szczególną uwagę na systemy zasilania awaryjnego (zasilacze bezprzerwowe UPS, zespoły prądotwórcze, ekologiczne rozwiązania $\mathrm{w}$ postaci paneli solarnych czy generatorów energii elektrycznej napędzanych siłą wiatru). 
Przeprowadzona analiza tych rozwiązań pozwala stwierdzić, iż zastosowanie ich umożliwia zwiększenie wartości wskaźników niezawodnościowo-eksploatacyjnych systemów zasilania.

Od zasilaczy stosowanych $\mathrm{w}$ transporcie (zarówno do zasilania systemów teleinformatycznych jak i pojazdów $[7,11,23])$, a w szczególności $\mathrm{w}$ transportowych systemach bezpieczeństwa $[8,20,26]$ wymaga się spełnienia wielu istotnych kryteriów. Należy do nich zaliczyć m. in. wysoką sprawność, miniaturyzację, odpowiednią funkcjonalność, zgodność $\mathrm{z}$ obowiązującym prawem[9], dużą niezawodność [10,14], możliwość diagnozowania w poszczególnych stanach eksploatacyjnych z uwzględnieniem jakości informacji [22], odporność na zakłócenia elektromagnetyczne [16,17,19] i wibracje [4]. Spełnienie tych oczekiwań wymaga znajomości wiarygodnych modeli niezawodnościowo-eksploatacyjnych systemów zasilających.

\section{Analiza niezawodnościowa zasilaczy}

Podczas analizy niezawodnościowo-funkcjonalnej zasilacza, można stwierdzić, iż zachodzące w nim relacje, mogą być przedstawione tak jak na rys. 1. Schemat ten nie zawiera wszystkich przypadków możliwych zmian stanu zasilacza (np. nie pokazuje przejścia ze stanu niezdatności $\mathrm{S}_{\mathrm{N}}$ do stanu pełnej zdatności $\mathrm{S}_{\mathrm{PZ}}$ ).

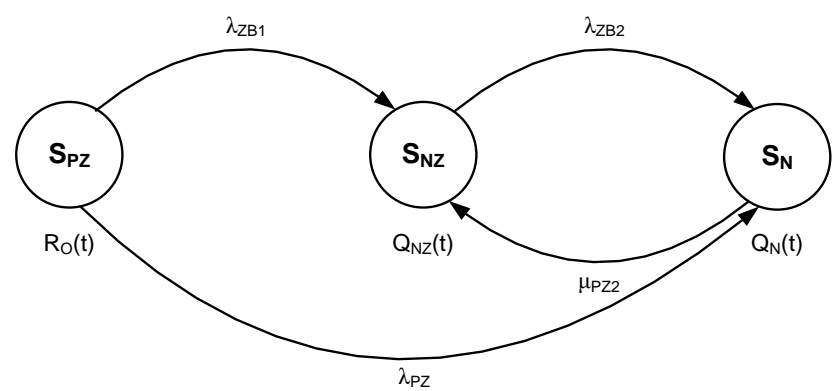

Rys. 1 Relacje w uktadzie zasilacza [opracowanie własne]

Oznaczenia na rys.1: $R_{O}(t)$ - funkcja prawdopodobieństwa przebywania systemu w stanie petnej zdatności $S_{P Z}, Q_{N Z}(t)$ - funkcja prawdopodobieństwa przebywania systemu $w$ stanie niepetnej zdatności $S_{N Z}, Q_{N}(t)$ - funkcja prawdopodobieństwa przebywania systemu $w$ stanie niezdatności $S_{N}, \lambda_{Z B 1}$ - intensywność przejść ze stanu petnej zdatności $S_{P Z}$ do stanu niepetnej zdatności $S_{N Z}, \lambda_{Z B 2}$ - intensywność przejść ze stanu niepetnej zdatności $S_{N Z}$ do stanu niezdatności $S_{N}, \mu_{P Z 2}-$ intensywność przejść ze stanu niezdatności $S_{N}$ do stanu niepetnej zdatności $S_{N Z}, \lambda_{P Z}$-intensywność przejść ze stanu petnej zdatności $S_{P Z}$ do stanu niezdatności $S_{N}$.

Stan pełnej zdatności $S_{\mathrm{PZ}}$ jest stanem oznaczającym zarówno zdatność techniczną jak i funkcjonalną. Zasilacz spełnia wszystkie wymagania eksploatacyjne. Stan niepełnej zdatności $\mathrm{S}_{\mathrm{NZ}}$ jest stanem oznaczającym niepełną zdatność techniczną i ograniczoną (np. w sensie czasu użytkowania i/lub poziomu generowanej mocy) zdatność funkcjonalną. 
Modelling of power supplies reliability in aspect of their technical...

Modelowanie niezawodności zasilaczy w aspekcie stanu technicznego...

Stan niezdatności $\mathrm{S}_{\mathrm{N}}$ jest stanem oznaczającym niezdatność zarówno techniczną jak i funkcjonalną. Zasilacz nie spełnia większości wymagań eksploatacyjnych. Jeśli system zasilania jest $\mathrm{w}$ stanie pełnej zdatności $\mathrm{S}_{\mathrm{PZ}}$ i pojawia się uszkodzenie niekrytyczne to następuje przejście systemu do stanu niepełnej zdatności $S_{\mathrm{NZ}}$ $\mathrm{z}$ intensywnością $\lambda_{\mathrm{ZB} 1}$.

Gdy istnieje stan niepełnej zdatności $\mathrm{S}_{\mathrm{NZ}}$ a dodatkowo pojawia się uszkodzenie krytyczne to następuje przejście do stanu niezdatności $S_{N} Z$ intensywnością $\lambda_{Z B 2}$. Zwrotne przejście do stanu niepełnej zdatności $S_{\mathrm{NZ}}$ ze stanu niezdatności $S_{\mathrm{N}}$ jest możliwe pod warunkiem podjęcia działań polegających na przywróceniu wymaganych (tj. co najmniej dopuszczalnych) właściwości energii na wyjściu zasilacza.

Gdy istnieje stan pełnej zdatności $\mathrm{S}_{\mathrm{PZ}}$ i pojawia się uszkodzenie krytyczne, to następuje przejście do stanu niezdatności $\mathrm{S}_{\mathrm{N}}$.

System przedstawiony na rys. 1 może być opisany następującymi równaniami Kołmogorowa-Chapmana:

$$
\begin{aligned}
& R_{0}^{\prime}(t)=-\lambda_{Z B 1} \cdot R_{0}(t)-\lambda_{P Z} \cdot R_{0}(t) \\
& Q_{N Z}^{\prime}(t)=\lambda_{Z B 1} \cdot R_{0}(t)-\lambda_{Z B 2} \cdot Q_{N Z}(t)+\mu_{P Z 2} \cdot Q_{N}(t) \\
& Q_{N}^{\prime}(t)=\lambda_{Z B 2} \cdot Q_{N Z}(t)-\mu_{P Z 2} \cdot Q_{N}(t)+\lambda_{P Z} \cdot R_{0}(t)
\end{aligned}
$$

Przyjmując warunki początkowe:

$$
\begin{aligned}
& R_{0}(O)=1 \\
& Q_{N Z}(O)=Q_{N}(O)=0
\end{aligned}
$$

i stosując przekształcenie Laplace'a otrzymujemy następujący układ równań liniowych:

$$
\begin{aligned}
& s \cdot R_{0}^{*}(s)-1=-\lambda_{Z B 1} \cdot R_{0}^{*}(s)-\lambda_{P Z} \cdot R_{0}^{*}(s) \\
& s \cdot Q_{N Z}^{*}(s)=\lambda_{Z B 1} \cdot R_{0}^{*}(s)-\lambda_{Z B 2} \cdot Q_{N Z}^{*}(s)+\mu_{P Z 2} \cdot Q_{N}^{*}(s) \\
& s \cdot Q_{N}^{*}(s)=\lambda_{Z B 2} \cdot Q_{N Z}^{*}(s)-\mu_{P Z 2} \cdot Q_{N}^{*}(s)+\lambda_{P Z} \cdot R_{0}^{*}(s)
\end{aligned}
$$

Prawdopodobieństwa przebywania systemu $w$ wyróżnionych stanach funkcjonalnych w ujęciu symbolicznym (Laplace'a) mają postać następującą:

$$
\begin{gathered}
R_{0}^{*}(s)=\frac{1}{s+\lambda_{P Z}+\lambda_{Z B 1}} \\
Q_{N Z}^{*}(s)=\frac{s \cdot \lambda_{Z B 1}+\lambda_{P Z} \cdot \mu_{P Z 2}+\lambda_{Z B 1} \cdot \mu_{P Z 2}}{s^{2} \cdot \lambda_{P Z}+s^{2} \cdot \lambda_{Z B 1}+s^{2} \cdot \lambda_{Z B 2}+s^{2} \cdot \mu_{P Z 2}+s^{3}+} \\
+s \cdot \lambda_{P Z} \cdot \lambda_{Z B 2}+s \cdot \lambda_{P Z} \cdot \mu_{P Z 2}+s \cdot \lambda_{Z B 1} \cdot \lambda_{Z B 2}+s \cdot \lambda_{Z B 1} \cdot \mu_{P Z 2} \\
Q_{N}^{*}(s)=\frac{s \cdot \lambda_{P Z}+\lambda_{P Z} \cdot \lambda_{Z B 2}+\lambda_{Z B 1} \cdot \lambda_{Z B 2}}{s^{2} \cdot \lambda_{P Z}+s^{2} \cdot \lambda_{Z B 1}+s^{2} \cdot \lambda_{Z B 2}+s^{2} \cdot \mu_{P Z 2}+s^{3}+} \\
+s \cdot \lambda_{P Z} \cdot \lambda_{Z B 2}+s \cdot \lambda_{P Z} \cdot \mu_{P Z 2}+s \cdot \lambda_{Z B 1} \cdot \lambda_{Z B 2}+s \cdot \lambda_{Z B 1} \cdot \mu_{P Z 2}
\end{gathered}
$$


Rozwiązanie powyższego zestawu równań w dziedzinie czasu jest kolejnym etapem analizy i nie jest tu omawiane.

\section{Modelowanie niezawodności zasilaczy}

Metody obliczeniowe i badania symulacyjno-komputerowe dają możliwość stosunkowo szybkiego określenia wpływu zmian wskaźników niezawodnościowoeksploatacyjnych poszczególnych modułów na wartości wskaźników opisujących kompletny zasilacz.

Stosując wspomaganie komputerowe można wyznaczyć wartości prawdopodobieństw przebywania zasilacza $\mathrm{w}$ stanach pełnej zdatności $\mathrm{S}_{\mathrm{PZ}}$, niepełnej zdatności $\mathrm{S}_{\mathrm{NZ}}$ i niezdatności $\mathrm{S}_{\mathrm{N}}$. Postępowanie takie przedstawia poniższy przykład.

\section{Przykład}

Przyjmijmy następujące wartości opisujące analizowany układ:

- czas badań - 1 rok:

$$
\mathrm{t}=8760[h]
$$

- nieuszkadzalność zasilacza (w zakresie uszkodzeń niekrytycznych):

$$
\mathrm{R}_{\mathrm{ZB} 1}(t)=0,999
$$

- nieuszkadzalność zasilacza (w zakresie uszkodzeń krytycznych):

$$
\mathrm{R}_{\mathrm{ZB} 2}(t)=0,9999
$$

- intensywność przejść ze stanu niezdatności do stanu niepełnej zdatności:

$$
\mu_{\mathrm{PZ2}}=0,1\left[\frac{1}{h}\right]
$$

- intensywność przejść ze stanu pełnej zdatności do stanu niezdatności:

$$
\lambda_{\mathrm{PZ}}=1,141558 \cdot 10^{-9}\left[\frac{1}{h}\right]
$$

Dla przyjętej wartości nieuszkadzalności $\mathrm{R}_{\mathrm{ZB} 1}(t)$, można oszacować intensywność przejść ze stanu pełnej zdatności do stanu niepełnej zdatności. Zakładając najprostszy, wykładniczy model rozkładu czasu zdatności, można wykorzystać następującą zależność:

$$
\mathrm{R}_{\mathrm{ZB} 1}(\mathrm{t})=\mathrm{e}^{-\lambda_{\mathrm{ZB} 1} \mathrm{t}} \text { dla } t \geq 0
$$

więc

$$
\lambda_{\mathrm{ZB} 1}=-\frac{\ln \mathrm{R}_{\mathrm{ZB} 1}(\mathrm{t})}{\mathrm{t}}
$$


Modelling of power supplies reliability in aspect of their technical...

Modelowanie niezawodności zasilaczy w aspekcie stanu technicznego...

A zatem dla $\mathrm{t}=8760[h]$ i $\mathrm{R}_{\mathrm{ZB} 1}(t)=0,999$ otrzymujemy:

$$
\lambda_{\mathrm{ZB} 1}=-\frac{\ln \mathrm{R}_{\mathrm{ZB} 1}(\mathrm{t})}{\mathrm{t}}=-\frac{\ln 0,999}{8760}=1,142124 \cdot 10^{-7}\left[\frac{1}{\mathrm{~h}}\right]
$$

Dla przyjętej wartości nieuszkadzalności $\mathrm{R}_{\mathrm{ZB} 2}(t)$, można oszacować intensywność przejść ze stanu niepełnej zdatności do stanu niezdatności. W przypadku rozkładu wykładniczego czasu zdatności mamy następującą zależność:

$$
\mathrm{R}_{\mathrm{ZB} 2}(\mathrm{t})=\mathrm{e}^{-\lambda_{\mathrm{ZB} 2} \mathrm{t}} \text { dla } t \geq 0
$$

więc

$$
\lambda_{\mathrm{ZB} 2}=-\frac{\ln \mathrm{R}_{\mathrm{ZB} 2}(\mathrm{t})}{\mathrm{t}}
$$

Dla $\mathrm{t}=8760[h]$ i $\mathrm{R}_{\mathrm{ZB} 2}(t)=0,9999$ otrzymujemy:

$$
\lambda_{\mathrm{ZB} 2}=-\frac{\ln \mathrm{R}_{\mathrm{ZB} 2}(\mathrm{t})}{\mathrm{t}}=-\frac{\ln 0,9999}{8760}=1,141609 \cdot 10^{-8}\left[\frac{1}{\mathrm{~h}}\right]
$$

Dla powyższych wartości wejściowych, przy wykorzystaniu równań (4), oraz odwrotnych transformat Laplace'a, otrzymujemy:

$$
\begin{aligned}
& R_{0}=0,99899 \\
& Q_{Z B}=0,0010099 \\
& Q_{B}=1,151923 \cdot 10^{-8}
\end{aligned}
$$

Intensywność przejść ze stanu niezdatności do stanu niepełnej zdatności $\mu_{P Z 2}$ jest - jak wiadomo (w przypadku wykładniczego rozkładu) - odwrotnością czasu $t_{P Z 2}$ :

$$
\mu_{P Z 2}=\frac{1}{t_{P Z 2}}
$$

Jeśli przyjmiemy, że czas na przywrócenie stanu niepełnej zdatności $t_{P Z 2}$ może zawierać się $\mathrm{w}$ przedziale $t_{P Z 2} \in\langle 12 ; 168\rangle[h]$ (czyli po przeliczeniu na dni $\left.t_{P Z 2} \in\langle 0,5 ; 7\rangle[d o b a]\right)$, to prawdopodobieństwo przebywania analizowanego zasilacza $w$ stanie niepełnej zdatności ilustruje wykres przedstawiony na rys. 2 . Wartości czasu $t_{P Z 2}$ przyjęto na podstawie obserwacji rzeczywistych systemów. 


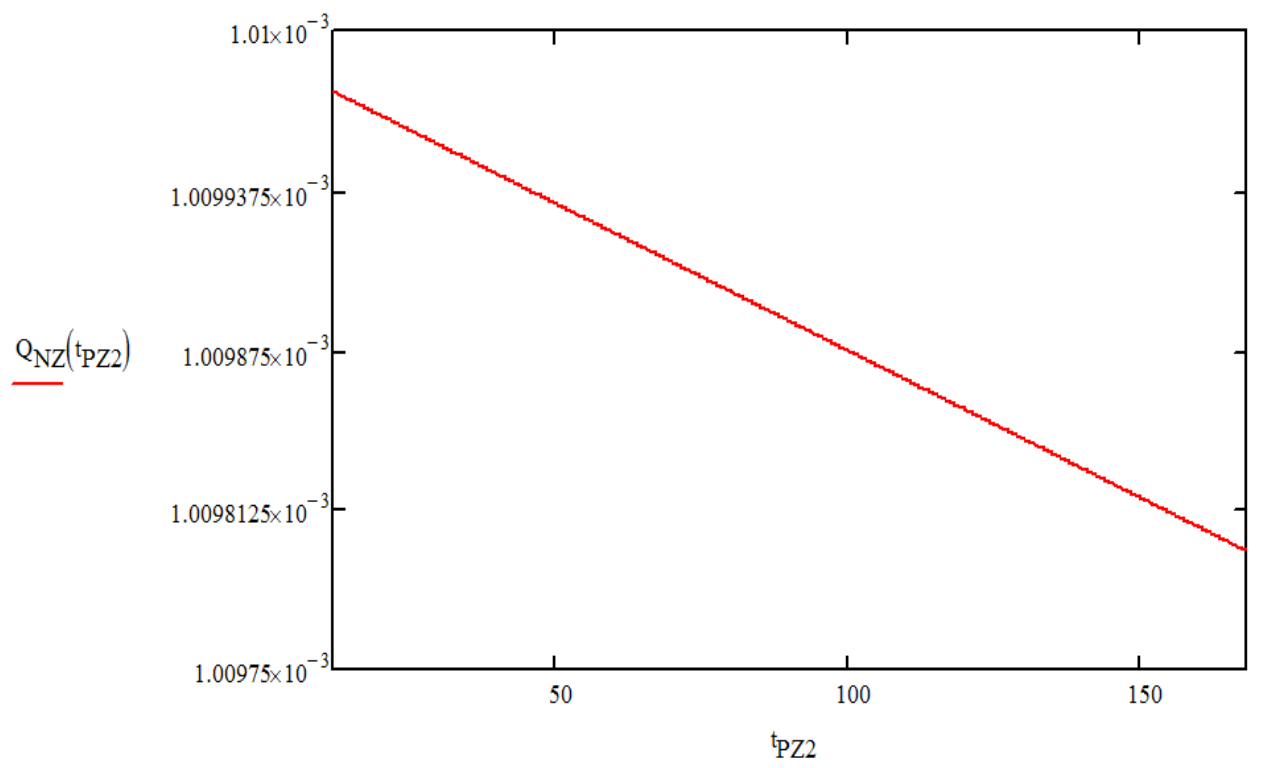

Rys. 2 Ilustracja prawdopodobieństwa przebywania zasilacza $w$ stanie niepetnej zdatności $S_{N Z} w$ funkcji dostępnego czasu na przywrócenie stanu niepetnej zdatności $t_{P Z 2}$

\section{Wnioski}

W opracowaniu zaprezentowano fragmenty analizy niezawodności zasilacza ze szczególnym uwzględnieniem rozróżnienia jego stanów niezdatności i niepełnej zdatności. Przedstawiono graf relacji niezawodnościowych zasilacza. Wyznaczono zależności umożliwiające obliczenie prawdopodobieństw przebywania systemu zasilacza $\mathrm{w}$ wyróżnionych stanach. $\mathrm{W}$ dalszych badaniach tego zagadnienia warto dążyć do określenia zależności między nakładami finansowymi, związanymi z dostępnym i wymaganym czasem przywrócenia stanu niepełnej zdatności oraz pełnej zdatności, a prawdopodobieństwem przebywania systemu w tych stanach.

\section{Literatura}

[1] Baggini A.: (editor) Handbook of power quality. John Wiley \& Sons, 2008.

[2] Będkowski L., Dąbrowski T.: Podstawy eksploatacji, cz. II Podstawy niezawodności eksploatacyjnej. Warszawa: Wojskowa Akademia Techniczna, 2006.

[3] Billinton R., Allan R. N.: Reliability evaluation of power systems. New York: Plenum Press, 1996. 
Modelling of power supplies reliability in aspect of their technical...

Modelowanie niezawodności zasilaczy w aspekcie stanu technicznego...

[4] Burdzik R., Konieczny Ł., Figlus T.: Concept of on-board comfort vibration monitoring system for vehicles. J. Mikulski (Ed.): Activities of Transport Telematics, TST 2013, CCIS 395. Springer, Heidelberg 2013. pp. 418-425.

[5] Dyduch J., Paś J., Rosiński A.: Podstawy eksploatacji transportowych systemów elektronicznych. Wydawnictwo Politechniki Radomskiej, Radom 2011.

[6] Epstein B., Weissman I.: Mathematical models for systems reliability. CRC Press / Taylor \& Francis Group, 2008.

[7] Kasprzyk Z., Siergiejczyk M.: Some Problems of Functional Analysis of Electronic Toll Collection System (ViaToll). In the monograph Activities of transport telematics, given as the monographic publishing series „Communications in Computer and Information Science”, Vol. 395. SpringerVerlag, Berlin Heidelberg, 2013, pp. 426-432.

[8] Kierzkowski A., Kisiel T.: Airport security screeners reliability analysis. In: „Proceedings of the IEEE International Conference on Industrial Engineering and Engineering Management IEEM 2015”, Singapore 2015. pp. 1158-1163.

[9] Krzykowski M.: Ochrona odbiorców wrażliwych energii elektrycznej i paliw gazowych - uwarunkowania prawne. Polityka Energetyczna - Energy Policy Journal, tom 17, zeszyt 3, 2014. str. 257-268.

[10] Laskowski D., Łubkowski P., Pawlak E., Stańczyk P.: Anthropotechnical systems reliability. In: the monograph ,Safety and Reliability: Methodology and Applications - Proceedings of the European Safety and Reliability Conference ESREL 2014", editors: Nowakowski T., Młyńczak M., JodejkoPietruczuk A. \&Werbińska-Wojciechowska S. CRC Press/Balkema, London, 2015, pp. 399-407.

[11] Lewczuk K., Zak J., Pyza D., Jacyna-Gołda I.: Vehicle routing in an urban area: Environmental and technological determinants. WIT Transactions on the Built Environment, Vol.130, 2013. pp. 373-384.

[12] Paś J.: Eksploatacja elektronicznych systemów transportowych. Uniwersytet Technologiczno - Humanistyczny, Radom 2015.

[13] Rosiński A.: Modelowanie procesu eksploatacji systemów telematyki transportu. Oficyna Wydawnicza Politechniki Warszawskiej, Warszawa 2015.

[14] Rosiński A.: Reliability-exploitation analysis of power supply in transport telematics system. In: „Safety and Reliability: Methodology and Applications - Proceedings of the European Safety and Reliability Conference ESREL2014", editors: Nowakowski T., Młyńczak M., Jodejko-Pietruczuk A.,Werbińska-Wojciechowska S. CRC Press/Balkema, 2015. pp. 343-347. 
[15] Siergiejczyk M., Krzykowska K., Rosiński A.: Reliability assessment of integrated airport surface surveillance system. In: „Proceedings of the Tenth International Conference on Dependability and Complex Systems DepCoSRELCOMEX", editors: W. Zamojski, J. Mazurkiewicz, J. Sugier, T. Walkowiak, J. Kacprzyk, given as the monographic publishing series „Advances in intelligent systems and computing”, Vol. 365. Springer, 2015, pp. 435-443.

[16] Siergiejczyk M., Paś J., Rosiński A.: Issue of reliability-exploitation evaluation of electronic transport systems used in the railway environment with consideration of electromagnetic interference. IETIntelligent Transport Systems 2016, doi: 10.1049/iet-its.2015.0183.

[17] Siergiejczyk M., Paś J., Rosiński A.: Train call recorder and electromagnetic interference. Diagnostyka 2015, vol. 16, no. 1, pp. 19-22.

[18] Siergiejczyk M., Rosiński A., Krzykowska K.: Reliability assessment of supporting satellite system EGNOS. In W. Zamojski, J. Mazurkiewicz, J. Sugier, T. Walkowiak, J. Kacprzyk (eds) New results in dependability and computer systems, given as the monographic publishing series - „Advances in intelligent and soft computing", Vol. 224. Springer, 2013. pp. 353-364.

[19] Siergiejczyk M., Rosiński A., Paś J.: Analysis of unintended electromagnetic fields generated by safety system control panels. Diagnostyka 2016, vol. 17, no. 3 , pp. 35-40.

[20] Skorupski J., Uchroński P.: A fuzzy reasoning system for evaluating the efficiency of cabin luggage screening at airports. TransportationResearch Part C - Emerging Technologies 54, 2015, pp. 157-175.

[21] Sozański J.: Niezawodność i jakość pracy systemu elektroenergetycznego. Warszawa: WNT, 1990.

[22] Stawowy M., Dziula P.: Comparison of uncertainty multilayer models of impact of teleinformation devices reliability on information quality. In: "Proceedings of the European Safety and Reliability Conference ESREL 2015”, editors: L. Podofillini, B. Sudret, B. Stojadinovic, E. Zio, W. Kröger. CRC Press/Balkema, 2015. pp. 2685-2691.

[23] Sumila M.: Selected aspects of message transmission management in ITS systems. In: the monograph „Telematics in the transport environment”, editors: Jerzy Mikulski, given as the monographic publishing series „Communications in Computer and Information Science”, Vol. 329. SpringerVerlag, Berlin Heidelberg 2012, pp. 141-147.

[24] Wiatr J., Miegoń M.: Zasilacze UPS oraz baterie akumulatorów w układach zasilania gwarantowanego. Warszawa: Dom Wydawniczy MEDIUM, 2008. 
Modelling of power supplies reliability in aspect of their technical...

Modelowanie niezawodności zasilaczy w aspekcie stanu technicznego...

[25] Wiatr J.: Zespoły prądotwórcze w układach awaryjnego zasilania obiektów budowlanych. Warszawa: Dom Wydawniczy MEDIUM, 2009.

[26] Wiśnios M., Dąbrowski T., Bednarek M.: Metoda zwiększania poziomu bezpieczeństwa zapewnianego przez system biometrycznej kontroli dostępu. Przegląd Elektrotechniczny 2015, nr 10, s. 229-232.

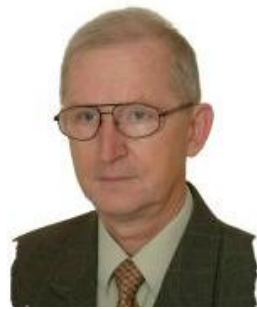

Dr hab. inz. Tadeusz Dąbrowski, profesor nadzwyczajny na Wydziale Elektroniki Wojskowej Akademii Technicznej. Jego zainteresowania naukowe koncentruja sie $w$ obszarze teorii eksploatacji - gtównie na diagnostyce technicznej. Do ważniejszych zagadnień, którymi się zajmuje należą: diagnostyka obiektów technicznych $i$ systemów antropotechnicznych, optymalizacja procesów diagnostyczno-obshugowych, niezawodność eksploatacyjna obiektów (Udział 33,3\%).

Dr inz. Jerzy Chmiel, adiunkt na Wydziale Transportu Politechniki Warszawskiej. Jego zainteresowania naukowe obejmuja aspekty zwiazane z niezawodnościa elementów i urządzeń elektronicznych, ze szczególnym uwzględnieniem zastosowań ich w systemach telematyki transportu oraz kwestie ich bezpieczeństwa (Udział 33,3\%).

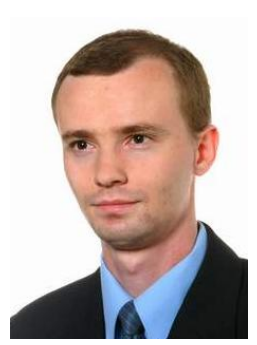

Dr hab. inż. Adam Rosiński, adiunkt na Wydziale Elektroniki Wojskowej Akademii Technicznej. Jego zainteresowania naukowe obejmuja analize niezawodnościowo-eksploatacyjna systemów telematyki transportu oraz inteligentnych systemów transportowych. $W$ dorobku naukowym posiada kilkadziesiąt publikacji naukowych (Udziat 33,3\%). 